日顎変形誌 Jpn. J. Jaw Deform. 2 (1) : 70〜78, April, 1992

\title{
上顎臼歯部歯槽骨切り術による骨格性開咬の治療
}

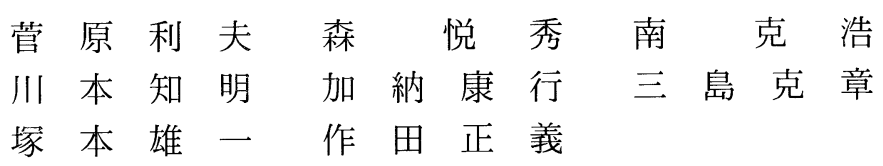

\section{Maxillary Posterior Segmental Osteotomy for Correction of Skeletal Open Bite}

\author{
Toshio SUGahara, Yoshinide MORI, Katsuhiro MiNAMI, \\ TOMOAKI KAWAMOTO, YASUYUKI KANO, KATSUAKI MISHIMA, \\ YUICHI TSUKAMOTO and MASAYOSHI SAKUDA
}

\begin{abstract}
The treatment of skeletal anterior open bite deformity using the single-stage maxillary posterior segmental osteotomy has been followed for 5 years to evaluate the final outcome of the operation. The clinical and radiographic examination during the control period show a remarkable stable result without a relapse. Treatment planning based on clinical, ceahalometric, dental plaster model examination and tongue posture analysis allows the accurate and predictable correction of this deformity. In addition, tongue posture had shifted from anteriorly and superiorly to posteriorly and inferiorly after surgery. The stable occlusion and this improvement of tongue posture after maxillary posteriorly segmental ostentomy is an effective surgical procedure for the skeletal open bite.
\end{abstract}

Key words : skeletal anterior open bite (骨格性前歯部開咬), maxillary posterior segmental osteotomy (上顎臼歯部歯槽骨切り術), tongue posture (舌位)

[Received Nov. 30, 1991]

\section{緒言}

骨格性開咬の外科的顎矯正法として，下顎にお ける下顎枝矢状分割術や上顎における Le Fort I 型骨切り術, 前歯部歯槽骨切り術, 臼歯部歯槽 骨切り術などが単独あるいは組合されて用いられ ている ${ }^{1)}$ が，術後に比較的高頻度の後戻りが見ら れることから，骨格性開咬は治療困難な不正咬合 の一つと考えられている ${ }^{1-9)}$ 。

1955年 Schuchardt ${ }^{10)}$ によって発表された上顎 臼歯部歯槽骨切り術は両側臼歯部歯槽の骨切りに よって臼歯歯槽骨片を上方に移動させ，前歯部の
開咬を改善する手術法であるが，術後早期に高頻 度の後戻りが抗こるとの報告 ${ }^{2-4)}$ が見られること から，本法の適応について一定の評価が得られて いないと思われる。

われわれは骨格性開咬に対し, 上顎且歯部歯槽 骨切り術による治療を行い，長期に安定した咬合 状態が得られた症例を経験したので, その治療経 過と，開咬の発現に深く関わっていると考えられ る舌の位置変化とともに報告する。

\section{症例}

患者：26歳 4 か月，女性

大阪大学歯学部口腔外科学第 2 講座（主任 : 作田正義教授）

The Second Department of Oral and Maxillofacial Surgery, Faculty of Dentistry, Osaka University

(Chief : Prof. Masayoshi SAKUDA) 


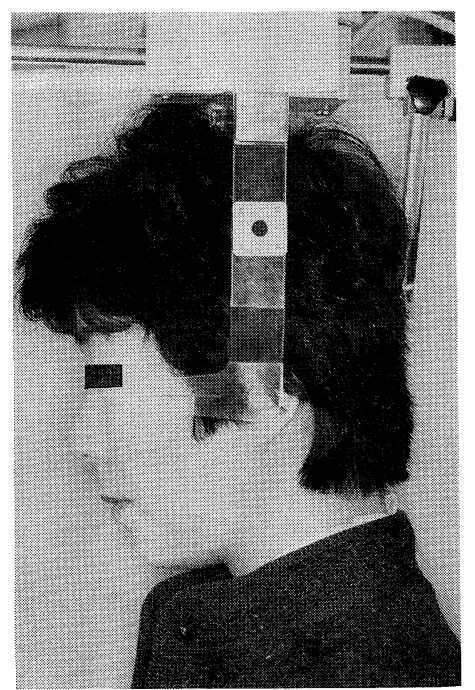

Fig. 1 Appearance pre-treatment of profile.

主訴：開咬による咀嚼障害

家族歴：両親および姉は正常咬合であり，三親 等以内の家系にも顎顔面形態の異常は認められな かった。

現病歴：18歳時に左右顎関節の疼痛を認め当科 を受診し，約 1 年間，スプリント療法と薬物療法 をうけ症状は消失した。当時より開咬を認めてい たが開咬に対する処置は望んでいなかった。26歳 時に開咬の審美的改善を希望して当科を再受診し た。

既往歴：特記事項なし。

\section{現 症}

全身的所見：身長 $165 \mathrm{~cm}$ ，体重 $56 \mathrm{~kg}$ で全身状 態良好であった。

顔貌所見：正貌は左右対称であるが，口裂閉鎖 時にオトガイ部の軽度の緊張感と僅かながら下顔 面高の延長が認められた。側貌ではオトガイ部の 後退を認めた (Fig. 1)。

口腔内所見：歯は第二大臼歯まですべて萌出し， 喪失歯はなかった。上顎の左右第三大臼歯は先天 性欠損であり，下顎の左右第三大臼歯は X線像よ りみて埋伏状態にあった。歯列は上䪽左右側第一 小曰歯の口蓋側転位と下顎前歯部の軽度の叢生が 見られ，上顎正中に対し，下顎正中は左側へ約 2 $\mathrm{mm}$ 偏位していた。咬合は上下顎大臼歯のみが

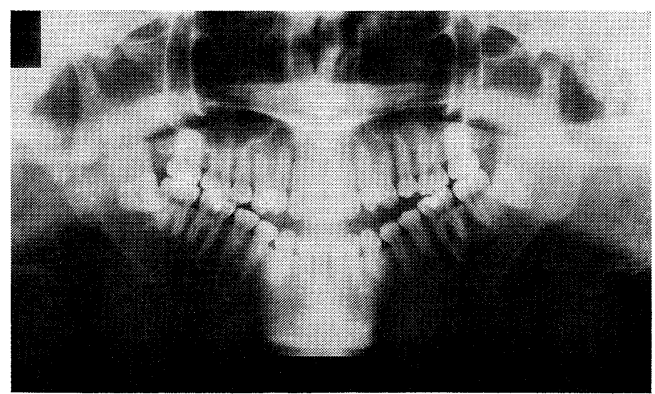

Fig. 2 Pre-treatment panoramic x-ray.

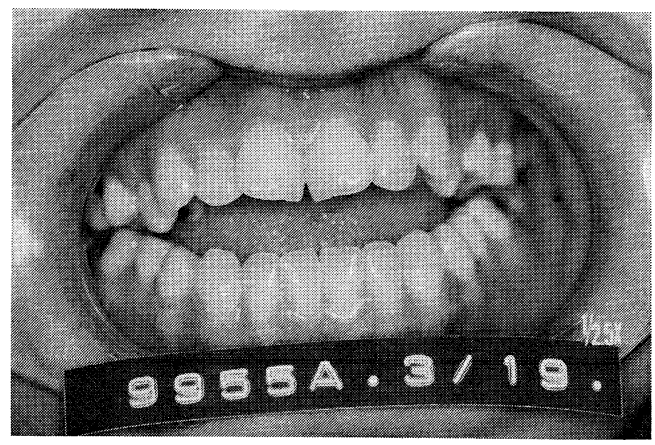

Fig. 3 Pre-treatment occlusion. Note : contact of molars only.

接触し, overjet $5.0 \mathrm{~mm}$, overbite $-6.5 \mathrm{~mm}$, 咬 合関係は Angle I 級であった。歯列模型分析で は，歯冠幅径の総和と歯槽基底弓の大きさは調和 がとれていた。また臨床的に巨舌は認められなか った (Fig. 2，3)。

頭部X線規格写真分析所見：上下顎骨の位置的 関係は前後的には正常であったが，垂直的には前 顔面高とくに前下顔面高の過大と後顔面高の短小 を認めた。下頡骨は後下方に回転し，下顎下縁平 面の急傾斜を認めた。上下顎前歯の歯軸はそれぞ れ口蓋側および舌側へ 1S.D. 傾斜し，上下顎第 一大曰歯の高位を認めた。また上唇下縁と上顎前 歯切縁の位置関係は正常であった（Fig. 4,5, Table. 1)。

舌，舌骨の位置分析所見：下顎安静位における 舌のX線撮影方法および舌，舌骨，咽頭腔に関す る計測法は，尾関の方法 ${ }^{11)}$ に従って行った（Fig. $6)$ 。

舌尖の垂直的位置 TT-OP は3S.D., 前後的位 置 TT-L1は4S.D. を越えて小さく, 舌背の咬合 平面に対する高さ DHO は1S.D. を越えて大き 
かった。すなわち正常人に比べ舌尖は前上方に，

舌背は後上方に位置していた。

舌骨は H-PMP が2S.D., H-Ar, H-Me が1S.

D. を越えて小さく，舌背の位置は正常咬合者に 比べ後上方位にあった。気道に関する前後径の計
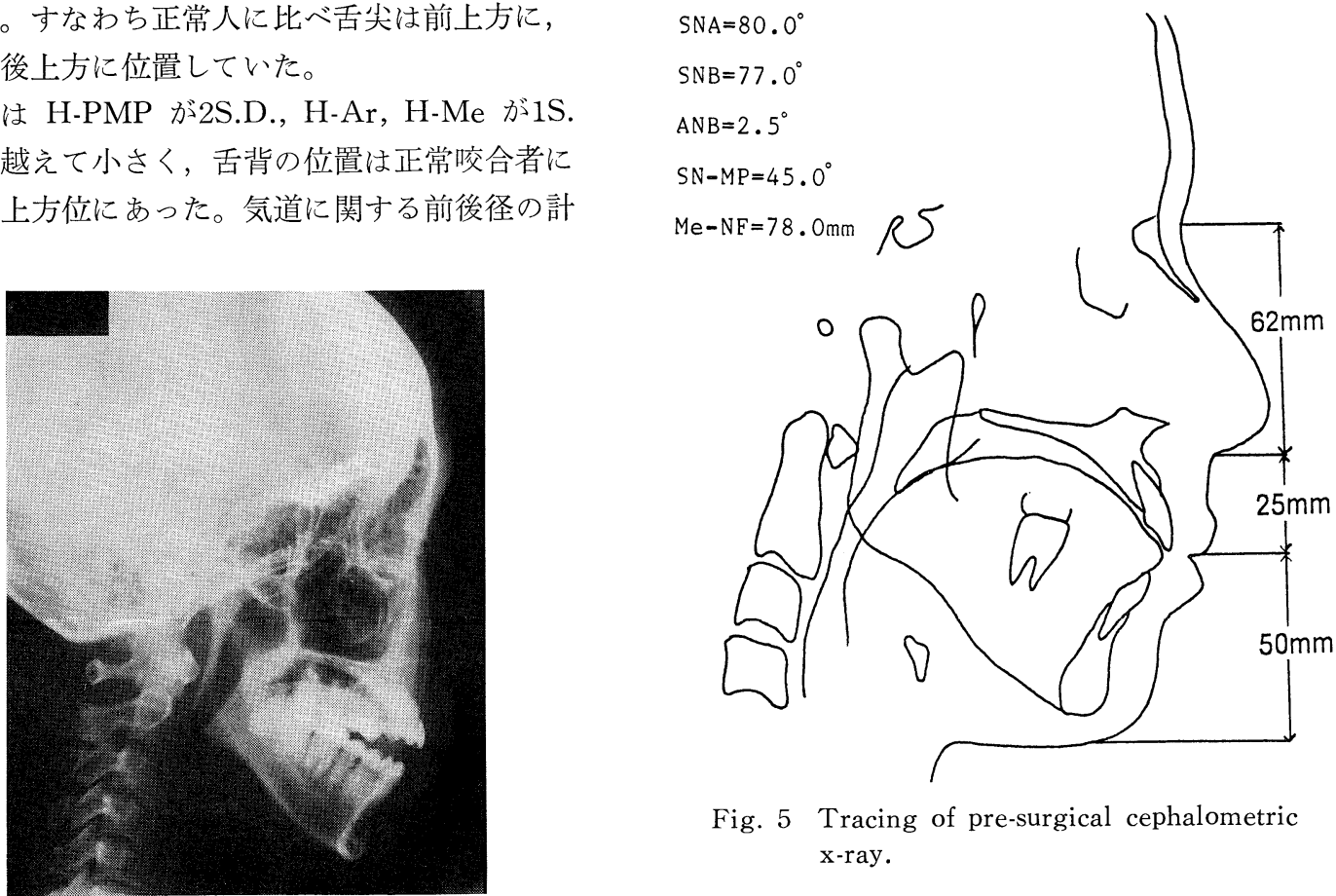

Fig. 5 Tracing of pre-surgical cephalometric $\mathrm{x}$-ray.

Fig. 4 pre-treatment cephalometric $\mathrm{x}$-ray.

Taple 1 Cephalometric measurements

\begin{tabular}{|c|c|c|c|c|c|}
\hline \multicolumn{3}{|c|}{ 角 度 計 測 } & \multicolumn{3}{|c|}{ 距 離 計 測 } \\
\hline & 術 前 & 術 後 & & 術 前 & 術 後 \\
\hline Facial A & 79.0 & 80.0 & N-S & 68.0 & 68.0 \\
\hline $\mathrm{Y} \cdot \mathrm{Axis}$ & 72.5 & 71.5 & $\mathrm{~N}-\mathrm{Me}$ & 131.0 & 128.0 \\
\hline NAP & 174.5 & 177.0 & $\mathrm{~S}-\mathrm{Ar}(\mathrm{FH})$ & 14.0 & 15.0 \\
\hline FH-SN & 2.0 & 2.0 & N-NF & 57.0 & 57.0 \\
\hline SNA & 80.0 & 80.0 & $\mathrm{Me}-\mathrm{NF}$ & 78.0 & 74.0 \\
\hline SNB & 77.0 & 78.5 & S-NF & 48.5 & 48.5 \\
\hline MP-SN & 45.0 & 41.5 & Go-NF & 32.0 & 31.5 \\
\hline MP-FH & 44.0 & 39.0 & $\mathrm{~A}-\mathrm{Ptm}(\mathrm{NF})$ & 45.5 & 45.5 \\
\hline SN-RP & 103.0 & 101.5 & Ar-Go & 44.0 & 44.0 \\
\hline Gonial A & 122.0 & 122.0 & Go-Me & 76.5 & 76.5 \\
\hline ANB & 2.5 & 1.5 & $\mathrm{Ar}-\mathrm{Me}$ & 10.5 & 10.5 \\
\hline NF-MP & 38.0 & 34.5 & ABR-B(MP) & 54.0 & 53.0 \\
\hline Interincisal-A & 118.5 & 118.5 & $\mathrm{~A}-\mathrm{B}(\mathrm{NF})$ & 5.5 & 4.5 \\
\hline U1-SN & 109.5 & 112.0 & Overjet & 5.0 & 3.0 \\
\hline U1-FH & 112.5 & 114.5 & Overbite & -6.5 & 2.0 \\
\hline L1-MP & 95.0 & 95.5 & Ptm-U6 & 18.0 & 21.0 \\
\hline $\mathrm{L} 1-\mathrm{FH}$ & 55.0 & 53.5 & A-U6(PP) & 27.5 & 25.0 \\
\hline \multirow[t]{3}{*}{ L1-AP } & 26.5 & 27.5 & ABR-L6 & 19.5 & 19.5 \\
\hline & & & B-L6(MP) & 34.0 & 33.5 \\
\hline & & & L1-AP & 7.0 & 9.0 \\
\hline
\end{tabular}




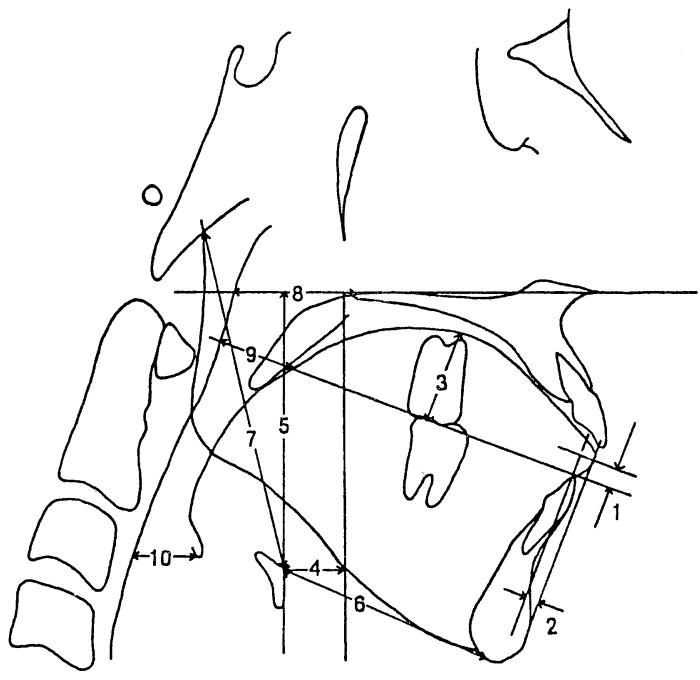

Fig. 6 Establishment of tongue measurements. 1. TT-OP, 2.TT-L1, 3. DHO, 4. H-PMP, 5. H-PP, 6. H-Mc, 7. H-Ar, 8. PNS-UPW 9. PDW-MPW, 10. E-LPW.

Table 2 Pre and post-treatment tongue posture analysis

\begin{tabular}{r|l|r|r}
\hline \multicolumn{2}{l|}{} & 術 前 & 術 後 \\
\hline 1 & TT-OP & 3.0 & 0.5 \\
2 & TT-L1 & 3.0 & 6.5 \\
3 & DHO & 23.0 & 18.0 \\
4 & H-PMP & -13.0 & -11.5 \\
5 & H-PP & 60.5 & 60.5 \\
6 & H-Mc & 47.5 & 46.5 \\
7 & H-Ar & 75.0 & 77.0 \\
8 & PDh-MPW & 27.0 & 27.0 \\
9 & PNS-UPW & 12.5 & 16.5 \\
10 & E-LPW & 13.5 & 12.0 \\
\hline
\end{tabular}

測では上下咽頭部の前後径 PNS-UPW, E-LPW は平均的であったが中咽頭部 PDH-MPW で狭 くなっていた (Table. 2)。

\section{診断}

前歯部開咬を伴う Angle I 級の不正咬合と診 断した。また上下顎大臼歯の高位が認められ, 舌 位に関しては舌尖が前上方に, 舌背が高位に位置 していた。

\section{治療経過}

エッジワイズ法により 1 年 4 か月の術前矯正治

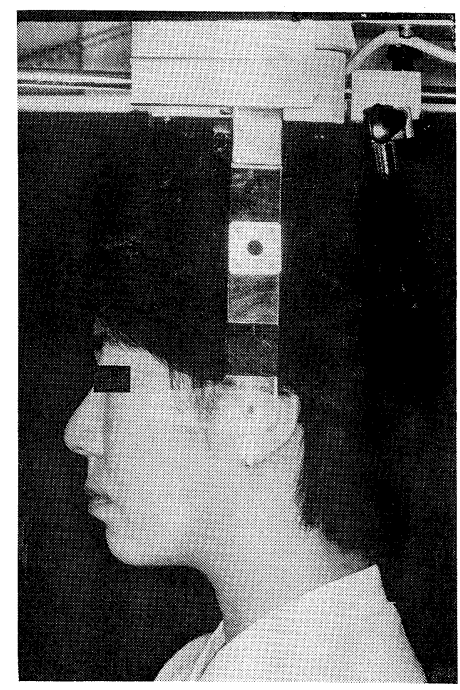

Fig. 7 Appearance 5 years post-treatment.

療を行った後, 上顭臼歯部歯槽骨切り術を Kufner ${ }^{12)}$ の方法に準じて行った。なお左右の犬歯歯 根の遠心傾斜を術前矯正により修正できなかった ので, 骨切りによる犬歯歯根の損傷を避けるため, 術中に第一小臼歯を抜去し, その部位から骨切り を行った。

骨切り後, 白歯部歯槽を術前の計画通り上方へ 移動し, あらかじめ半調節性咬合器上でモデルサ ージェリーにより overbiteを $2 \mathrm{~mm}$, overjet を $3 \mathrm{~mm}$ に設定して作製したバイトスプリントを 上顎歯列に適合させて装着し，バイトスプリント を左右煩骨弓に $0.5 \mathrm{~mm}$ ステンレス線で懸架し た。術後 6 週間目にバイトスプリントを除去し, 約 7 か月の術後矯正治療の後, 保定に移った。保 定は開咬を積極的に改善したり，再発を防止する 目的で，一般に使用される上下顎間のゴム毫引や バーチカルチンキャップなどは一切用いず，プレ ートタイプの保定装置を約 1 年間使用した。なお 術中に抜去した上顎第一小罒歯は接着性ブリッジ で補緅処置を行った。現在，保定終了後 4 年を経 過するが overbite の減少はみられず，咬合状態 は術直後と変化を認めず良好である。

\section{上顎臼歯部歯槽骨切り術後 6 カ月目の 治療成績}

顔貌所見：正貌では下顔面高が正常域になり， 側貌ではオトガイ部の後退感は改善した (Fig. 7)。 


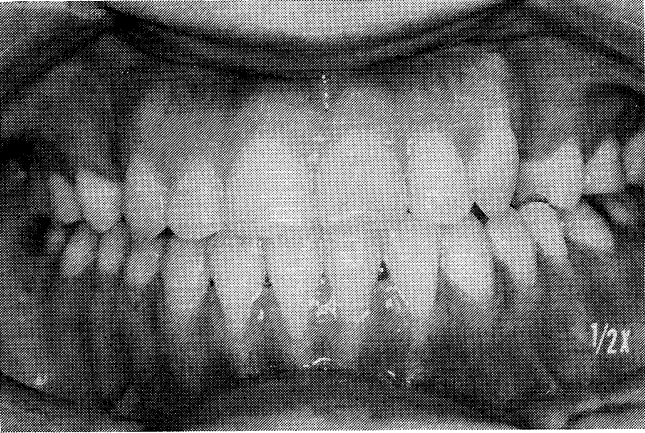

Fig. 8 Five years post-treatment occlusion.

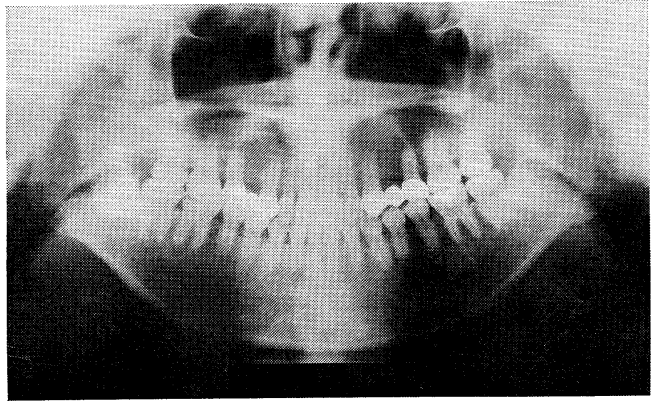

Fig. 9 Five years post-surgery panoramic x-ray.

口腔所見：上下顎の正中は一致し，咬合関係は Angle I 級で全歯にわたり咬合は良好であった。 Overbite, overjet に変化はなく, 電気歯髅診断 ではすべての歯に反応がみられ，歯根の吸収など の異常も認めなかった（Fig. 8，9）。

頭部X線規格写真所見 : 上顎臼歯部歯槽の上方 移動により下顎骨が前上方へ回転したため， B 点 の前方移動と下顎下縁平面の傾斜の改善が認めら れた (Fig. 10, 11, Table. 1)。

舌, 舌背の位置変化: 舌尖は前上方から後上方 へ, 舌背は下方へ移動した。舌背は前下方に移動 し, 上中下咽頭部の前後径は中咽頭部のみが大き くなった (Fig. 12, Table. 2)。

\section{保定終了後 4 年目の治療成績}

手術後 5 年, 顔貌, 口腔, 頭部 X線規格写真所 見, 舌・舌骨の位置変化などは術後 6 か月目と比 較し異常は認めず, 咬合も手術直後と変化はなか った。また顎関節の不快症状の発現はなく, 電気 歯髄診断および上顎洞の X線検查での異常や，そ の他臨床的不快症状も認めなかった。

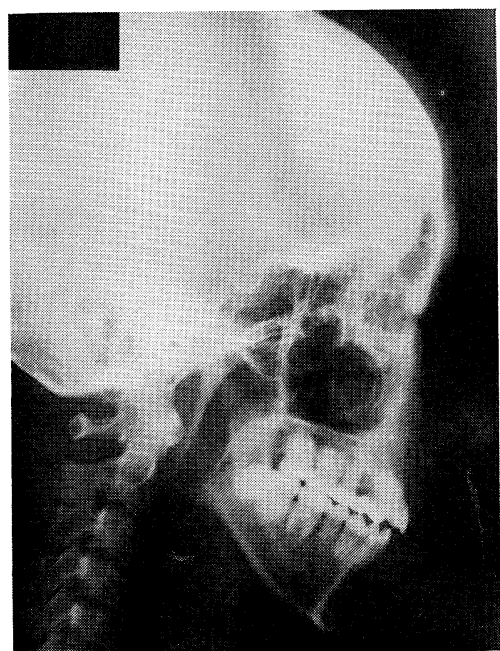

Fig. 10 Five years post-treatment cephalometric $\mathrm{x}$-ray.

$\mathrm{SNA}=80.0^{\circ}$
$\mathrm{SNB}=78.5^{\circ}$
$\mathrm{ANB}=1.5^{\circ}$
$\mathrm{SN}-\mathrm{MP}=41.5^{\circ}$

$\mathrm{Me}-\mathrm{NF}=74.0 \mathrm{~mm}$

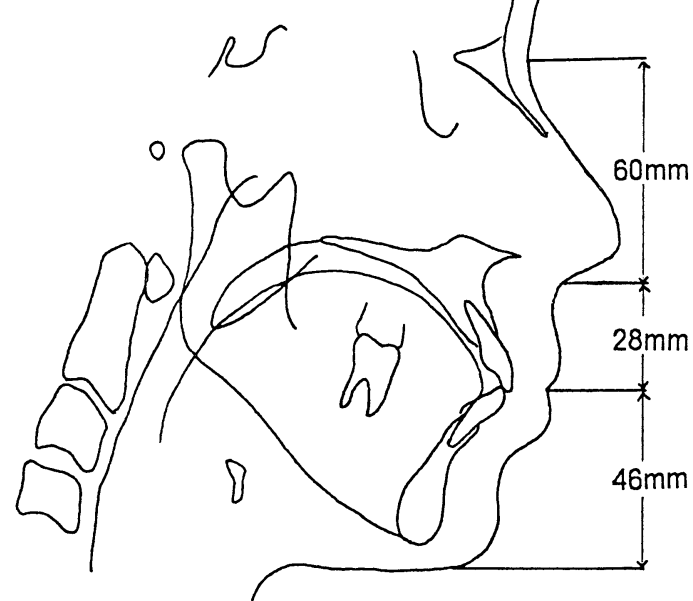

Fig. 11 Five years post-treatment cephalometric $\mathrm{x}$-ray tracing.

\section{考察}

骨格性開咬に対する治療法として，上顎骨にお いては前歯部歯槽骨切り術, 臼歯部歯槽骨切り術, Le Fort I 型骨切り術が，また下顎においては 前歯部歯槽骨切り術や下顎枝矢状分割術などのさ まざまな外科的顎矯正術が，単独あるいは組合さ 


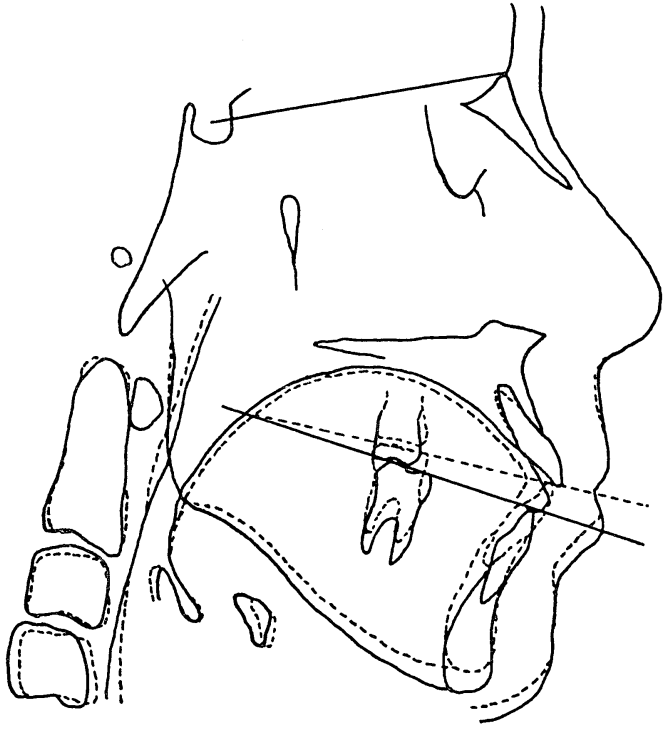

Fig. 12 Superimposed cephalometric tracings, pre-operation and 5 years post-operation, demonstrating post-operative anticlockwise rotations of the mandible and the tongue posture.

- Pre-treatment
$\ldots$. Post-treatment

れて行われている ${ }^{1)}$ が，術後にみられる高頻度の 後戻りのため治療法の選択には苦慮するところで ある。術後に正しい安定した咬合が得られ，審美 性にも優れた治療法を選択するためには，本症の 病態を明らかにし，術後に構成される新しい咬合 関係や口腔環境に咀嚼筋や舌などが順応し, 安定 した咬合状態が維持されるか否かを十分検討する 必要があると考えられる。

本症例での術式選択にあたっては，頭部X線規 格写真や歯列模型分析から明らかになった本症の 特徵である，下顎下縁平面の急傾斜，前下顔面高 の過大，後顔面高の短小，上顎大臼歯歯槽部の下 方への過成長や，上唇と上顎前歯切縁の位置関係 などを考慮した。

まず上顎前歯部歯槽骨切り術 ${ }^{13)}$ とよる開咬の改 善は上唇と前歯の位置関係を悪化させ，上顎前歯 部歯肉の露出といら審美的に好ましくない顔貌を きたす恐れがあるため術式の選択から除いた。

下顎枝矢状分割術は, 種々の骨格性の顎変形症 に適応を持つすぐれた治療法であると考えられて
おり，開咬の治療にも多く用いられ良好な成績が 報告されている ${ }^{14)}$ 。しかし Kannberg ${ }^{7)}$ や Man$z^{8)}$ は下顎枝矢状分割術を用いて治療した開咬症 例において, 時として, 垂直および水平の何れの 方向にも後戻りが起こることがあり，特に垂直方 向の後戻りがより大きいことを報告している。そ して，この後戻りは開咬を改善するための骨の移 動方向である反時計回りの回転移動のときの方が, 時計回りの回転移動のときより大きいこと，また， 後戻りの主な原因は異常舌癖や舌圧の影響, 咬筋, 側頭筋，内側翼突筋，顎二腹筋などの開閉口筋の 緊張, 特に顎二腹筋に代表される舌骨上筋群の骨 移動に伴う異常な伸展によるものであろうと報告 されている1,6,7)。

これに対して，上顎骨での処置である Le Fort I 型骨切り術は開閉口筋の直接的な影響を受けな いため, 術後の後戻りが少なく骨格性開咬の優れ た治療法であると考えられている ${ }^{15)}$ が，時として

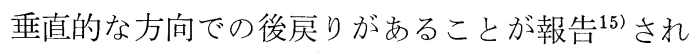
ている。 Lansley ${ }^{5)}$ は Le Fort I 型骨切り術に よる開咬の治療で, 後方臼歯部を上方へ移動させ ず，前歯部のみを下方に移動させて開咬を治療し た症例では，前歯部の持続的な上方への後戻りが あることを報告し，開咬症例の治療では上顎臼歯 部での上方への再配列による Maxillary plane angle の増大と前歯部での強固な骨接合の必要性 を説いている。

このように開咬の治療においては，下顎および 上顎の単独の手術では開咬の改善のための骨移動 量が大きくなり，術後に後戻りの危険が増大する と考えられるため，下顎枝矢状分割術と Le Fort I 型骨切り術を同時に行う全上下顎同時移動術が 行われることがある。

Lello $^{9)}$ は300例の開咬症例のうち，10症例に全 上下顎同時移動術を行い，4 年以上の経過観察で 3 例に再手術が必要な後戻りを認めている。後戻 りの部位は上下顎骨の単独手術の際に見られる部 位と同じで，上・下顎骨の後戻り量の比較では下 顎が大きく，開咬改善のために行う下顎骨の反時 計回りの回転移動の部位に，特に集中しているこ とが観察されている。

一方，上䫟骨における $⿴$ 歯部歯槽骨切り術は 
Schuchardt 法 $^{10)}$ ともよばれ，1955年開咬の外科 的治療法として報告された。この方法は上顎臼歯 部歯槽を骨切りし，上方へ移動することにより， 下顎を回転させ開咬を改善させる術式であるが， Schuchardt は骨切り部の血行不全による骨壊死 を防止する目的で，第 1 回目の手術で口蓋側の骨 切りを行ない，その $3 \sim 4$ 週間後に煩側の骨切り を行う 2 期手術を行っているが，Kufner ${ }^{12)}$ はそ の術式を改良し，煩側および口蓋側の骨切りを同 時に行う 1 期手術を報告している。いずれの術式 を採用するにしても，この手術法は骨格性開咬で 下顔面高が高く，上唇と上顎前歯切縁との位置関 係が正常か, 上唇が短く上唇下縁が前歯部切縁よ り上方に位置しているような症例では，それらの 位置関係を悪化させることなく治療できるため, 審美性に優れた術式であると考えられている。し かし, 上顎臼歯部歯槽骨切り術は, 術後早期に高 度の後戻りをきたしやすく, 術式としての適応を 疑問視する報告 ${ }^{2-4)}$ もある。そして，後戻りの原因 としては異常な舌癖, 臼歯歯槽部の不完全な骨切 り，骨切り部である上顎臼歯歯槽部に付着し，上 唇へ走行している煩筋の作用, 手術前後の口腔内 容積と舌容積との不調和，短すぎる䫈間固定期間， また， 2 期法では初回手術後に形成された口蓋側 骨切り部の仮骨の骨性治癒不良が考えられてい

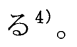

$\mathrm{Nwoku}^{4)}$ は以上挙げた 原因に十分な 注意を払 いながら，上頡臼歯部歯槽骨切り術による14症例 の開咬の治療を行い, 1 症例のレジンシーネによ る固定を行った症例を除き，21〜 46日間の顎間固 定を行い予後を観察した。結果は 1 期法， 2 期法 などの術式にかかわらず，すべての症例で後戻り を認め, その原因として，上䫟咬合平面挙上によ る安静空隙の増加と, 骨切りによる上顎洞容積の 変化に伴う空気圧の影響などが，関連しているか もしれないと述べている。

一方，Schwenzer ${ }^{16)}$ は20症例の開咬症例に対 して， 1 期法あるいは 2 期法の上顎臼歯部歯槽骨 切り術後，5週間の顎間固定を行い，経過観察の できた 15 症例中に 1 症例のみ開咬が残存したが, 術式にかかわらず 3 症例に部分的な後戻りを認め ただけの良好な成績を報告した。そして，本術式
の後戻りの原因は上方へ移動した上顎曰歯歯槽部 が後戻りするのではなく, 骨切り後に行われた暴 力的な臼歯部歯槽の上方移動之暴力的な顎間固定 により，顎関節窩から顎関節突起が引き出されて 固定されたため, 顎間固定解除後に関節突起が元 の位置に戻ろうとして, 咬合に異常が発生するの だろうと述べている。そして後戻りを防止するた めには田歯部歯槽の上方移動を確実に行い, 固定 することが最も重要であり, 本術式の適応症の正 しい選択と正確な手術を行えば本術式は有用性が 高いと報告している。

われわれは以上のような前歯部開咬に対する外 科的顎矯正法の背景を踏まえて本症例の術式を検 討した。本症例は上唇と上顎前歯切縁の位置関係 が正常であり, 前下顔面高の過大, 後下顔面高の 短小, そして下顎骨の後下方への回転と下顎下縁 平面の急傾斜を認めるが，下顎角の開大，下顎前 歯歯槽部の挺出, 上顎前歯歯槽部の上方転位は認 められないという形態的特徴をもっていた。そし てこれらの形態上の問題点を改善する術式の一つ として上顎臼歯部歯槽骨切り術が有効であると考 えられた。

一方, 舌, 舌骨の位置に関する検討では, 頭部 X線規格写真の分析から正常咬合者と比べて舌尖 の前上方位と舌背の高位および舌骨の後上方位を 認めた。顎変形症患者における舌, 舌骨の位置お よび外科的矯正手術における新しい口腔環境への 舌の順応性については，種々の意見が散見される が，下顎前突症において，舌は術後の新しい口腔 環境に適応寸るという Subtelny ${ }^{17)}$, Tulley ${ }^{18)} の$ 意見や, 適応せずに舌圧が増大し, 後戻りの原因 になるとする $\mathrm{Kole}^{19)}$ の意見などがある。吉田 ${ }^{201}$ は術前後の舌尖および舌背の位置を計測検討し， 舌尖が前上方位にあり, 舌背が高い症例では, 術 後の口腔容積の減少や被蓋関係の変化に対し, 舌 の機能的な適応は困難で, 咬合関係に不安定性を 招く可能性があると述べている。この点からも， 本症例の治療法としては下顎骨を前上方へ回転移 動させ，舌尖を後下方へ移動させる術式が望まし いことが推定された。

また Lowe ${ }^{21,22)}$ は，骨格性開咬の患者では下 顎の後下方への回転が上下顎中切歯の低位, 臼歯 
部歯牙の高位, overbite の過小と関連している こと，そして本症例と同様に正常咬合者に比べ舌 尖が前上方位に, 舌背が高位に, 舌骨が後上方位 に位置しているため, 安静時の舌の圧力が歯の位 置に影響を与え，前歯部開咬をひきおこすと推定 している。これらの点からも，本症例の骨格性開 咬の外科矯正治療は, 上顎臼歯部を上方一移動さ せることにより，下顎を反時計回りに回転させ， 前歯部開咬を改善させること，そして，下顎骨の 移動によっておこる舌の後下方への移動により， 舌尖の位置を前上方位から後下方へ修正すること のできる上顎臼歯部歯槽骨切り術が，術後の安定 した咬合を維持できる術式であると考えられたた め，本術式を最終的に選択した。

術後の頭部 X線規格写真による分析から，予定 通りの骨の移動が得られたことが確認されるとと もに，経時的な後戻りは認められず，術式の選択 および治療の妥当性が裏付けられ，上䫟臼歯部歯 槽骨切り術の有用性が証明された。また舌位置の 検討でも，舌尖の前上方位，舌背の高位，舌骨の 後上方位という本症の位置的特徴は術式選択時の 予測通り，下顎の反時計回りである前上方への回 転により外舌筋の位置変化が惹起され, 舌尖は後 下方, 舌背は下方, 舌骨は前下方位へと移動し, 安定した口腔および骨格形態が得られ，後戻りの ない安定した咬合が維持されている。また舌およ び舌骨の位置が正常位に戻ったことにより，強い 垂直成分の保定力が不必要となり，開咬症例の術 後の後戻りに対処するため, 従来使用されていた 長期間のバーチカル・チンキャップや顎間ゴムに よる铱引力を用いることもなく，比較的短期間の プレートタイプの保定を行うのみで，保定後の 4 年間の経過観察で後戻りを認めていない。

\section{結語}

骨格性開咬症例の外科的顎矯正に際し，上顎臼 歯部歯槽の上方移動により，下顎骨に反時計回り の回転を与え開咬を改善し，舌尖，舌背，舌骨の 位置を修正することにより，術後の安定した口腔 環境と骨格形態が得られるという推論から，上顎 臼歯部歯槽骨切り術を行った。術後 5 年間の経過 観察で後戻りのない安定した咬合が維持されてい
ること, また舌尖, 舌背, 舌骨などが当初の予定 通り移動していることが確認され，われわれの手 術計画の妥当性とその理論的背景が正しいことが 証明され，今後の開咬症例の治療にあたっては骨 格形態だけでなく舌, 舌骨の位置についても十分 検討する必要があると考えられた。

\section{引用文献}

1) Kwon, H. J., et al.: Apertognathia (open bite) and its surgical management. Int J Oral Surg $13: 278-289,1984$.

2) Köle, H.: Die chirurgische Behandlung des offenen Bisses. Ost. Z. Stomat. 64 : 255-263, 1967.

3) Obwegeser, H.: Der offene Biß in chirurgische Sicht. Schweiz. Mschr. Zahnheilk. 74:668687, 1964.

4) Nwoku, A. L.: Ergebnisse der chirurgischen Korrektur des offenen Bisses nach Schuchardt. Fortschr. d. Kiefer-und Gesichtschir 18:209-211, 1981.

5) Lansley, C. V., et al.: Relapse following surgical treatment of anterior open bite. $\mathrm{Br} \mathrm{J} \mathrm{O}$ ral Maxillofac Surg $24:$ 391-404, 1986.

6) McNeill, R. W., et al.: Skeletal relapse during intermaxillary fixation. J Oral Surg 31 : 212-227, 1973.

7) Kawnberg, K. E., et al.: Surgical treatment of the open bite deformity. Int J Oral Maxillofac Surg $17: 45-48,1987$.

8) Manz, E., et al. : Spätergebnisse der Korrektur des skelettal offenen Bisses durch sagittale spaltung der Unterkiefers. Fortschr. d. Kiefer-und Gesichtschir. 26 : 64-66, 1981.

9) Lello, G. E. : Skeletal open bite correction by combined Le Fort I osteotomy and bilateral sagittal split of the mandibular ramus. J. Craniomaxillofac Surg 15:132-136, 1987.

10) Schuchardt, K.: Formen des offenen Bisses und ihre operativen Behandlungsmöglichkeiten. Fortschr. d. Kiefer-und Gesichtschir. 1:222-230, 1955.

11）尾関 哲, 他：X線法による舌の機能形態学的研究 のためのマーカーについて. 日矯歯誌，29:13-22, 1970.

12) Bell, W. H., et al.: Surgical correction of dentofacial deformities. 2 Saunders. London. 1980, p 332-336.

13) Wunderer, S.: Erfahrunger mit der operativen Behandlung hochgradiger prognathien. Dtsch. Zahn. Mund. Kieferheilk 39:451-456, 1963.

14) Obwegeser, H.: Indication for surgical correction of mandibular deformity by sagittal technique. Br J Oral Surg 1: 157-171, 1964.

15) Proffit, W. R., et al, : Surgical correction of 
dentofacial deformities. W. B. Saunders Co, Philadelphia 1980, p 1062-1063, 1094.

16) Schwenzer, N.: Hat sich die Korrektur des offenen Bisses nach Schuchardt bewährt. Fortschr. d. Kiefer-und Gesichtschir $26: 117-121$, 1981.

17) Subtelny, J. D. : Malocclusion, orthodontic corrections and orofacial muscle adaptation. Angle Orthod 40:170-201, 1970.

18) Tulley, W. J. : A critical appraisal of tongue thrusting. Am J Orthod 55:640-650, 1969.

19) Köle, H. : Results, experience and problem in the operative treatment of anomalies with re- verse overbite. Oral Surg Oral Med Oral Pathol $19: 427-450,1965$.

20）吉田建美：骨格性下顎前突症の外科的矯正治療に伴 う舌の機能的変化一頭部X線計測学的ならびに筋電 図学的研究. 阪大歯学誌, 31:351-358, 1986.

21) Lowe, A. A., et al. : Dentoskeletal and tongue soft-tissue correlates: A cephalometoric analysis of rest position. Am J Orthod 88 : 333-341, 1985.

22) Lowe, A. A. : The contribution of tongue muscle activity to the development of anterior open-bite malocclusions. 近東矯誌, $15: 25-34$, 1980 . 